\title{
Characterization mixtures of thick gypsum with addition of treated waste from laminated plasterboards
}

\author{
A. Rodríguez-Orejón ${ }^{\mathrm{a}} \bowtie$, M. del Río-Merino ${ }^{\mathrm{a}}$, F. Fernández-Martínez ${ }^{\mathrm{a}}$ \\ a. Universidad Politécnica de Madrid (Madrid, Spain) \\ \agustin.rodriguezo@upm.es
}

Received 8 May 2013

Accepted 22 November 2013

Available on line 03 June 2014

\begin{abstract}
Environmental protection involves the reuse of construction and demolition waste. In order to improve recycling, waste from laminated plasterboards is used in the cement and laminated gypsum boards manufacture.

This article analyzes the use of ground and burnt laminated plasterboard (BLG) waste mixed with thick gypsum (TG). Physical-mechanical characterization of superficial hardness and mechanical strength has been performed on different batches of plaster powder materials with different BLG waste particle sizes to determine its suitability. Coarse particle sizes were preferred in order to reduce the waste treatment. From all the mixtures studied, the one with the best results was $\mathrm{TG}+5 \% \mathrm{BLG}_{1.25}$ which forms a material of higher superficial hardness and strength. The results obtained in the study have proved suitable products for building use (both as renders and as prefabricated elements) enabling for a reduction in the consumption of natural resources.
\end{abstract}

KEY WORDS: Composite materials; Gypsum plaster; Laminated plasterboard; Waste

Citation/Citar como: Rodríguez-Orejón, A.; del Río Merino, M.; Fernández-Martinez, F. (2014) Characterization mixtures of thick gypsum with addition of treated waste from laminated plasterboards Mater. Construcc. 64 [314], e018 http:// dx.doi.org/10.3989/mc.2014.03413.

RESUMEN: Caracterización de la mezcla de yeso grueso con adición de residuos tratados de placas de yeso laminado. La protección del medio ambiente implica la reutilización de los residuos de construcción y demolición. Los residuos de placas de yeso laminado se utilizan en la fabricación de cemento y de placas de yeso laminado.

En este artículo se ha estudiado la utilización de residuos de placa de yeso laminado cocido (YLC) mezclado con yeso grueso (YG), realizándose la caracterización físico-mecánica de dureza superficial y resistencias mecánicas, para determinar su idoneidad formando materiales de yeso en polvo con distintas granulometrías de residuos de (YLC), teniendo preferencia por granulometrías gruesas, que reducen el tratamiento del residuo. De las mezclas estudiadas la que mejores resultados ha ofrecido es $\mathrm{YG}+5 \% \mathrm{YLC}_{1,25}$ formando un material de mayor dureza superficial y resistencia. De los resultados obtenidos en el estudio se puede afirmar que se han conseguido productos aptos para su utilización en edificación posibilitando una reducción del consumo de recursos naturales.

PALABRAS CLAVE: Materiales compuestos; Yeso; Placa de yeso laminado; Residuos

Copyright: (C) 2014 CSIC. This is an open-access article distributed under the terms of the Creative Commons Attribution-Non Commercial (by-nc) Spain 3.0 License. 


\section{INTRODUCTION}

The manufacture of laminated gypsum boards began at the end of the 19th century, although in Spain this manufacturing industry was delayed until the 1970s. These boards were applied initially, mainly, for the purpose of fire protection for the timber structures of buildings. However, together with the already known advantages of gypsum products - protection against fire and hygroscopicity - laminated plasterboards add also other advantages such as: good adaptability, lightness, speed of installation, good acoustic performance or even energy saving (1).

For this reason, the laminated plasterboards have become an essential material in building and interior decoration. In the current building construction, gypsum boards, together with plasterboards, have also applications in rehabilitation, restoration and decoration of interior spaces in old and emblematic buildings.

At the same time, the interest in the use of construction and demolition waste (CDW) in new buildings has gradually been growing, thereby reducing the environmental problem waste that the disposal causes. This waste includes prefabricated plaster materials, such as laminated plaster panels, which are products that alter the quality of the soil where they are deposited or react with the cement, mortar and concrete, when recycled aggregates are used due to their high content in $\mathrm{CaSO}_{4}$.

A significant number of research works have been performed where different industry waste and even CDW are incorporated in plasters to modify and improve physical or mechanical properties. Regarding the studies to increase its mechanical strength, plaster has been mixed with $\mathrm{E}$ and $\mathrm{AR}$ glass fibers (2), with short sisal fibers (agave sisalana) to facilitate the use of this material in the manufacture of building elements (3), with wood particles and recycled paper (4), or with not-combined cut polypropylene fibers with melamine-formaldehyde dispersions (5).

In relation to works focused on decreasing the weight of the prefabricated plaster, several studies analyzed gypsum matrix batches with various lightening additives used in mortar and cement or concrete (air-entraining agents, foaming agents, plasticizers and superplasticizers) (6), by adding crushed cork aggregates $(7,8)$, blending into the gypsum matrix expanded polystyrene beads $(9,10)$, or incorporating cellular solids (expanded perlite, vermiculite, cellular glass) (11).

In the literature studied, works addressing two features - a physical and a mechanical one-i.e. the decrease in density and increase in binding strength of gypsum by mixing it with a combination of polypropylene fibers and expanded polystyrene beads in a specific proportion to obtain adequate results (9), as well as the mixture of waste from expanded polystyrene (EPS) packaging grinding, with gypsum and plasters for construction use (10) have also been found.

However, no study has been found in the literature on the incorporation of laminated plasterboards waste to the gypsum matrix manufacturing process.

This waste, coming mainly from faulty laminated plasterboards of the manufacturing process and the subsequent quality control generates a noticeable waste quantity which, not being contaminated by other materials, allows for the recovery and recycling of the following products:

- Wet gypsum board, which has not fulfilled the prior to drying quality control.

- Dry gypsum boards, rejected after drying.

- Gypsum powder from other manufacturing stages, such as the cutting process of panels to the desired size for sale, etc., which is sucked in and filtered.

Currently, recycling these products is carried out through a simple process of crushing and sieving using a horizontal mesh and other auxiliary systems such as a worm drive gear with gravimetric classification, obtaining a recycled plaster containing a slightly higher cardboard content than the 1.3\% obtained with a $10 \mathrm{~mm}$ mesh screening, decreasing the percentage of cardboard below $0.3 \%$ with smaller than $1 \mathrm{~mm}$ span meshes. This provides a saving of raw materials and a reduction of the environmental impact $(12,13)$.

The resulting products are:

- Dehydrate gypsum of specific granulometry.

- Formation of cellulose briquettes, from paper, intended for reuse in the production process.

Currently in Spain, the Law 10/1998 which regulates waste management and sets guidelines for promoting its reduction through reuse, or reducing its disposal in landfills. It has created the need to develop specific plans for the different types of waste, being the Integrated National Plan of Waste for the period 2008-2015 (PNIR Spanish acronym) (14) the one currently in force in the Spanish territory.

The policy of CDW in Spain is in rather new and unfortunately the percentage of building materials recycled is only close to $5 \%$ of the total CDW produced. Currently, PYL is only recycled in the production processes (Knauf, Placo, Uralita...). However, in European countries the situation is quite different; mainly in Northern European countries (UK, Denmark, Norway, the Netherlands, or 
even Switzerland, etc.), where they reach up to $80 \%$ of recycled waste $(15,16)$.

This article, which is part of a broader research project where the behavior of different types of gypsum with addition of crushed and burnt laminated plasterboard waste is studied, contributes to valorize the waste from the laminated gypsum boards manufacture - a material used worldwide in the construction of internal partitions and suspended ceilings. This type of waste is included in the PNIR within the 2nd National Plan of Construction and Demolition Waste (II PNRCD Spanish acronym) when it is produced within an industrial activity and not being identified as hazardous in the European waste list (Order MAM/304/2002).

In addition, during the installation process, as well as during the process of building demolition, these waste products are classified as construction and demolition waste (CDW), included in chapter 17 of the European List of Waste: 170802 "Gypsum-based construction materials other than those contaminated with dangerous substances".

This work aims to find other uses of CDW originated from laminated plasterboards specifically by mixing a newly produced powder gypsum matrix with different proportions of this waste, previously treated. The study quantifies the variations suffered in mechanical strength and superficial hardness depending on the particle size and the proportion of the addition of crushed and burnt laminated gypsum board waste (BLG) in relation to the gypsum matrix without additions, to identify the most favorable BLG-matrix mix to be used in construction works.

\section{EXPERIMENTAL}

\subsection{Materials}

A gypsum matrix is used as the base to which crushed and burnt plasterboard (BLG) is incorporated. In particular:

Plaster. Plaster used throughout this research work is from PLACO Saint-Gobain company, Iberplas type Thick gypsum TG, designated as B1, according to UNE-EN 13279-1:09 standard "Yesos de construcción y conglomerantes a base de yeso para la construcción. Parte 1: Definiciones y especificaciones". Its technical features are:

Index of purity: $75 \%$

Particle size: $0-2 \mathrm{~mm}$

Superficial hardness: 45 Uds. Shore C

Compressive strength: $\geq 2 \mathrm{~N} / \mathrm{mm}^{2}$

Bending strength: $\geq 2 \mathrm{~N} / \mathrm{mm}^{2}$

Bonding: $>0.1 \mathrm{~N} / \mathrm{mm}^{2}$

$\mathrm{pH}:>6$

Addition. Laminated plasterboards have been crushed and sieved. Two sieves were used to get two different granulometries: a sieve of $1.25 \mathrm{~mm}$ openings and another one of $0.32 \mathrm{~mm}$, obtaining two products with particle sizes smaller than $1.25 \mathrm{~mm}$ and $0.32 \mathrm{~mm}$. Both products were subjected to heat treatment at $230{ }^{\circ} \mathrm{C}$ for 24 hours, obtaining two types of burnt laminated gypsum, BLG $_{1.25}$ and $\mathrm{BLG}_{0.32}$ respectively, which were the additions used.

\subsection{Experimental process}

The theoretical conditions established for the experimental process were:

a. After obtaining the burnt laminated gypsum additive, it was separated in two granulometric sizes:

- BLG passing through the $1.25 \mathrm{~mm}$ sieve, called BLG $_{1.25}$.

- BLG passing through the $0.32 \mathrm{~mm}$ sieve, called BLG $_{0.32}$.

Figure 1 shows the granulometric curves of the three products.

b. Setting percentages of BLG -of both sizes- to be mixed with the gypsum matrix. These percentages were set by previous tests performed, resulting in a range of 5 to $10 \%$. The analyzed percentages (Table 1) were as follows:

c. Fixing a constant water/plaster correlation, taking the average one obtained in the test according to the standard UNE-EN 13279-2:06 "Yesos de construcción y conglomerantes a base de yeso para la construcción. Parte 2: Métodos de ensayo".

Results obtained by the method of saturation mixing are presented in Figure 2, resulting in an average of $0.67 \mathrm{w} / \mathrm{p}$ which was used for all batches.

d. Determining the physical-mechanical characteristics of the two series; three specimens of $40 \times 40 \times 160 \mathrm{~mm}$ for each tested batch. These specimens were set at room temperature for seven days, and later introduced in the furnace at $40 \pm 5^{\circ} \mathrm{C}$ for 24 hours, as specified by the standard UNE-EN 13279-2:06 "Yesos de construcción y conglomerantes a base de yeso para la construcción. Parte 2: Métodos de ensayo".

- Determination of superficial hardness of different mixtures with a Shore $\mathrm{C}$ durometer, according to UNE 102042:13 standard "Yesos $y$ escayolas de construcción. Otros métodos de análisis" on the different specimen series performed. 


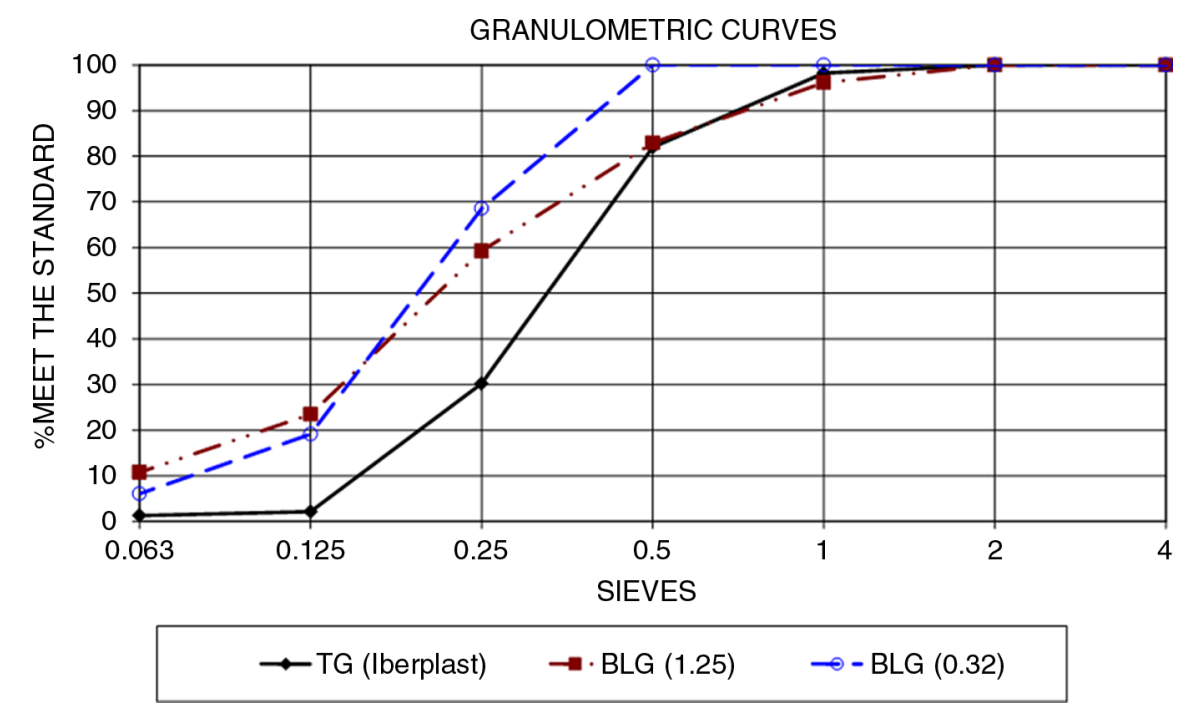

FIGURE 1. Granulometric curves.

The durometer used, reference 53505/C-4 BAXLO, has the following characteristics:

Scale: C

Sensitivity: 1 degree

- Determination of bending and compressive strength according to UNE-EN 13279-2:06 standard "Yesos de construcción y conglomerantes a base de yeso para la construcción. Parte 2: Métodos de ensayo", with a combined machine for compressive and bending tests, IBERTEST, Autotest -200/10- SW model, with the following characteristics:

Compression load capacity: $200 \mathrm{kN}$

Bending load capacity: $10 \mathrm{kN}$

Scales: 2 (1/1 and $1 / 5$ of the maximum load)

Measuring system: load cell of strain bands

Measurement range in compression zone: between 0.4 and $200 \mathrm{kN}$

Measurement range in bending zone: between 0.2 to $10 \mathrm{kN}$

TABLE 1. Batches used in the experimental process

\begin{tabular}{|c|c|c|c|}
\hline Type of binder & $\% \mathrm{BLG}_{1.25}{ }^{*}$ & $\% \mathrm{BLG}_{0.32} *$ & Batch name \\
\hline \multirow{7}{*}{$\begin{array}{l}\text { Thick Gypsum } \\
\text { (TG) }\end{array}$} & 0 & 0 & TG \\
\hline & 5 & 0 & $\mathrm{TG}+5 \% \mathrm{BLG}_{1.25}$ \\
\hline & 6 & 0 & $\mathrm{TG}+6 \% \mathrm{BLG}_{1.25}$ \\
\hline & 7 & 0 & $\mathrm{TG}+7 \% \mathrm{BLG}_{1.25}$ \\
\hline & 0 & 5 & $\mathrm{TG}+5 \% \mathrm{BLG}_{0.32}$ \\
\hline & 0 & 6 & $\mathrm{TG}+6 \% \mathrm{BLG}_{0.32}$ \\
\hline & 0 & 7 & $\mathrm{TG}+7 \% \mathrm{BLG}_{0.32}$ \\
\hline
\end{tabular}

(*) Percentage of BLG in relation to the binder weight used.
Experimental quantification of the material properties have been carried out in the Laboratory of Construction Materials, of the Department of Architectural Constructions, at the University School of Building Engineering, from the Technical University of Madrid.

\section{RESULTS AND DICUSSION}

The results obtained in the laboratory, on standardized prismatic specimens of $40 \times 40 \times 160 \mathrm{~mm}$, with two sets of three test specimens for each of the 7 mixtures studied, are as follow:

\subsection{Superficial hardness}

Figure 3 includes the data obtained in the Shore $\mathrm{C}$ hardness test. It can be observed, that the addition in different percentages, both of $\mathrm{BLG}_{1.25}$ and $\mathrm{BLG}_{0.32}$ shows as a result a substantial increase in the material hardness, being remarkable the hardness achieved by the batch TG $+7 \% \mathrm{BLG}_{1.25}$, which represents an increase of $5 \%$ over the $\mathrm{TG}$ paste, as well as the mix $\mathrm{TG}+5 \% \mathrm{BLG}_{0.32}$ which reaches a $4.3 \%$ increase.

\subsection{Bending strength}

Figure 4 shows the bending strength values obtained, showing the influence of each addition in different proportions. The horizontal line represents the value of the bending strength of the specimens corresponding to gypsum with no addition $\left(4.5 \mathrm{~N} / \mathrm{mm}^{2}\right)$.

In general terms a decrease in strength based on the percentage and grain size of the additive used can be observed, being a 5\% in gypsum weight admissible for additive contents or even the addition of $7 \%$ 
Characterization mixtures of thick gypsum with addition of treated waste from laminated plasterboards $\bullet 5$

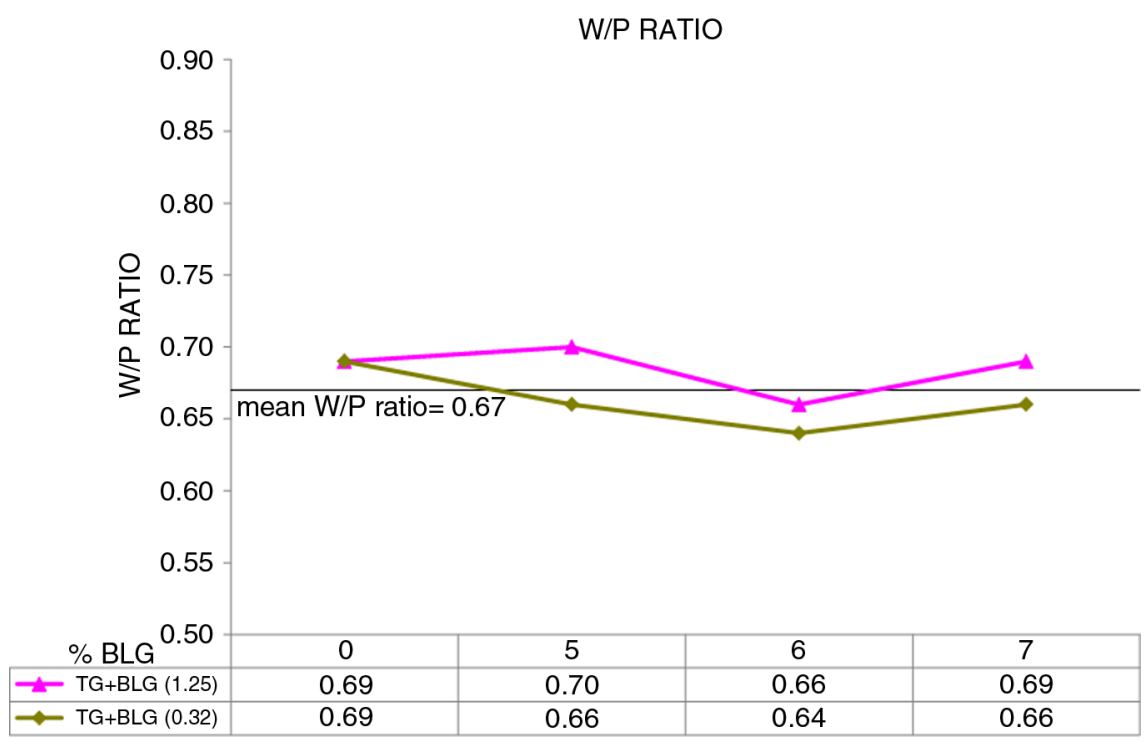

FIGURE 2. Water/plaster ratio.

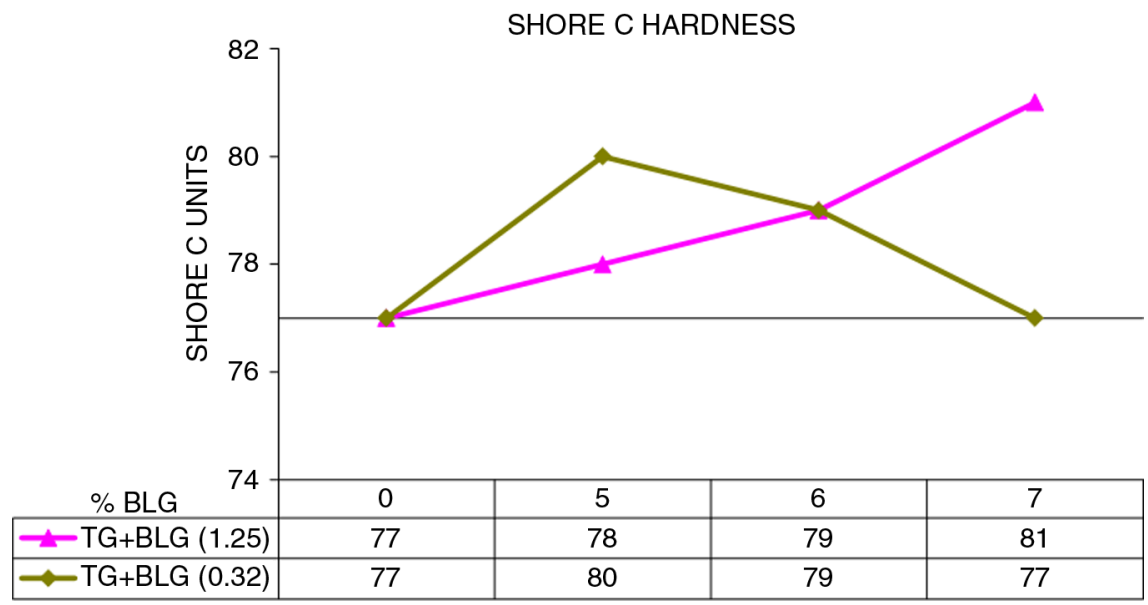

Figure 3. Superficial hardness (Shore C) test.

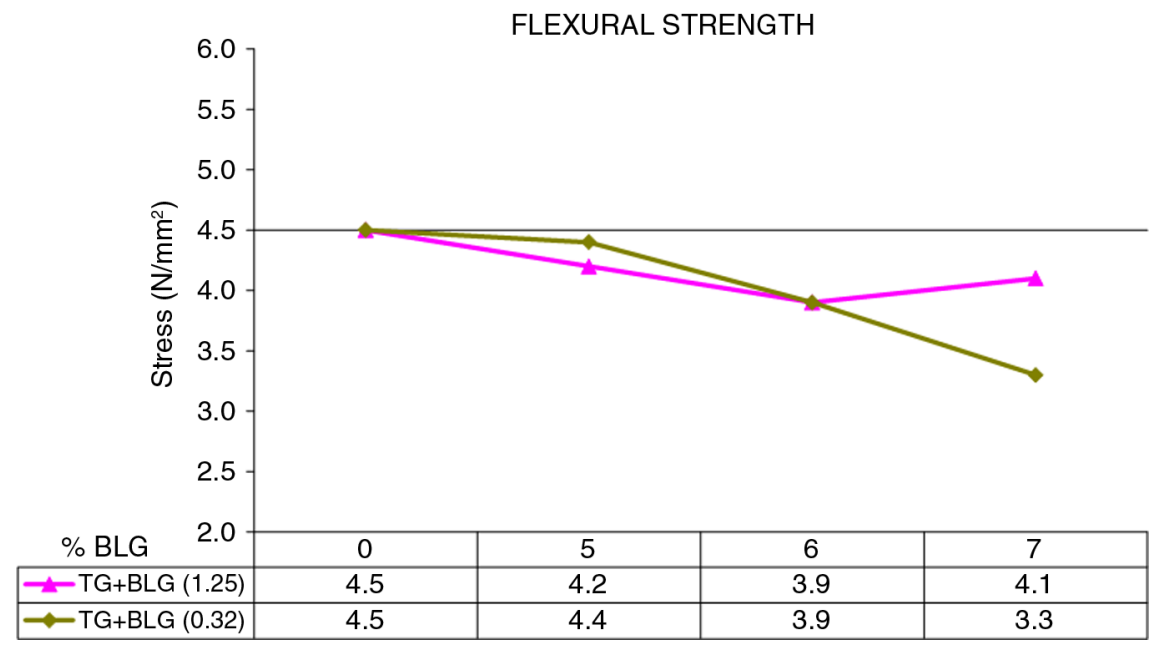

FIGURE 4. Bending strength test. 


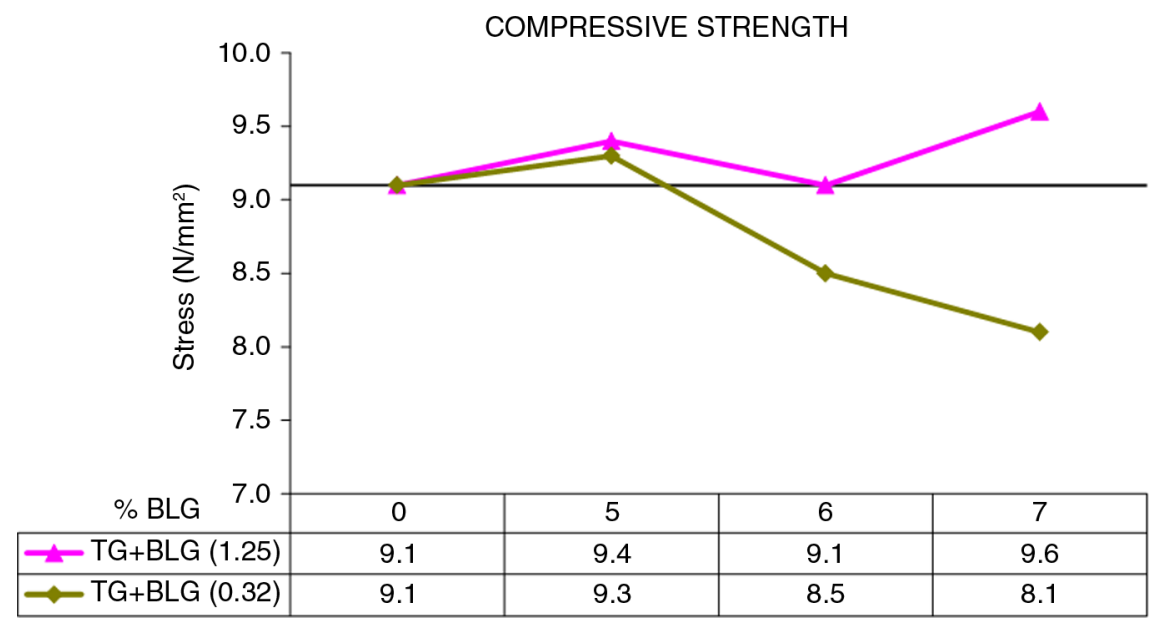

FIGURE 5. Compressive strength test.

when $\mathrm{BLG}_{1.25}$ is used, since none of them exceeds a decrease of $10 \%$ regarding TG batch.

\subsection{Compressive strength}

From the compressive strength test results obtained (Figure 5), an increase in compressive strength of gypsum specimens without additions can be stated for all mixtures with $B_{L} G_{1.25}$. Nevertheless, the same does not occur when performed with $\mathrm{BLG}_{0.32}$ where, except with the $5 \%$ addition, there is a strength decrease, being up to $-10 \%$ regarding the strength of the matrix without additions.

\section{CONCLUSIONS}

This research work proves that, based on the analyzed characteristics, the addition of different percentages of BLG waste, leads to an increase in superficial hardness of the resulting product and can be applied as renders and plasters, both horizontally and vertically. It also constitutes an improvement in the prefabricated elements (blocks, mouldings, etc.).

From all the tested batches, the one with most beneficial characteristics is $\mathrm{TG}+5 \% \mathrm{BLG}_{1.25}$, obtaining very suitable test results on the physicalmechanical characteristics. On the other hand, since it has a large particle size, savings in the process of obtaining the BLG waste is produced by reducing the grinding process.

In addition, the decreases of mechanical strength, both in bending and in compression, depend on the particle size of the addition. With fine-grained $\mathrm{BLG}_{0.32}$ the strength decrease is significantly higher than when using the large particle size $\mathrm{BLG}_{1.25}$. This may be due to an excessive contribution of "fines", creating a certain discontinuity of sizes that decreases the bonding between particles in the setting process.
On the other hand, the mixtures used, regardless of the size and percentage of the addition, allow us to obtain pastes and products that meet the specifications required by the standard UNE-EN 13279-1:08, which enable marketing and meet the requirements stated by AENOR and the EC standards.

The addition of this type of CDW to the thick gypsum matrix, allows to obtain thick gypsum powder and prefabricated plaster elements, achieving the reuse of this waste and generating savings from natural raw materials.

\section{REFERENCES}

1. Villanueva, L. (2004) Evolución histórica de la construcción con yeso. Informes de la Construcción, 56 [493], 5-11. http://dx.doi.org/10.3989/ic.2004.v56.i493.434

2. Río Merino, M.; Comino, P. (2002) Analysis of the strengthenings of mixed glass fibers $\mathrm{E}$ and fibers AR in plaster, as an alternative to monofiber (homogeneous) strengthenings. Mater. Construcc. 52 [268], 33-42. http://dx.doi.org/10.3989/ mc.2002.v52.i268.315.

3. Oteiza, I. (1993) Estudio del comportamiento de la escayola reforzada con fibras de sisal, para componentes en viviendas de bajo coste. Informes de la Construcción, 45 [425-426], 135144. http://dx.doi.org/10.3989/ic.1993.v45.i425-426.1190.

4. Haselein, C.R. (2002) Fabricaçao de chapas de partículas aglomeradas usando gesso como material cimentante. Ciencia Forestal, 12 [1], 81-87.

5. García Santos, A. (1988) "Modelo teórico del comportamiento mecánico del yeso y sus compuestos fibrosos poliméricos". Tesis Doctoral

6. Gázquez, M.J.; Bolívar, J.P.; Vaca, F.; García-Tenorio, R.; Mena-Nieto, A. (2012) Use of the "red gypsum" industrial waste as substitute of natural gypsum for commercial cements manufacturing. Mater. Construcc. 62 [306], 183-198. http://dx.doi.org/10.3989/mc.2011.63910.

7. Río Merino, M.; Hernández Olivares, F. (1998) Nuevos materiales compuestos de yeso-corcho. Arquimacom 98. Burdeos. Francia.

8. Río Merino, M.; Santa Cruz, J.; Hernández Olivares, F. (1999) "Yeso aligerado con corcho y su aplicación en paneles para construcción". Solicitud de patente. OTRI P9902034.

9. García Santos, A. (2009) PPF-reinforced, ESP-lightened gypsum plaster. Mater. Construcc. 59 [293], 105-124. http:// dx.doi.org/10.3989/mc.2009.41107. 
10. González Madariaga, F.J. (2008) "Mezclas de residuos de poliestireno expandido (EPS) conglomerados con yeso o escayola para su uso en la construcción”. Informes de la construcción, 60 [509], 35-43. http://dx.doi.org/10.3989/ ic.2008.v60.i509.589.

11. Río Merino, M.; Domínguez, J.D.; Hernández Olivares, F. (1998) Escayola aligerada con sólidos celulares. Informes de la construcción, 50 [458], 43-60. http://dx.doi.org/10.3989/ ic. 1998.v50.1458.878.

12. Fernández Casado, S. (2010) Reciclaje interno de los residuos en las fábricas. Reutilización del yeso reciclado para la fabricación de placas de yeso laminado (Comunicación Técnica) Congreso Nacional del Medio Ambiente. Madrid.

13. Onishi, K.; Fujino, T.; Kondo, Y.; Ikami, H.; Asaeda, T. (2012)Applicability of Recycled Gypsum Composite Mortar as Raw Material for Foundation Work of Single-family Houses. Journal of Asian Architecture and Building Engineering, 11 [1], 119-124.

14. Ministerio de Agricultura, Alimentación y Medio Ambiente. (2009) Plan Nacional Integrado de Residuos para el Periodo 2008-2015 BOE nº 49 (26/02/2009).

15. Lawson, N.; Douglas, I.; Garvin, S.; McGrath, C.; Manning, D.; Vetterlein, J. (2001) Recycling construction and demolition wastes - a UK perspective. Environmental Management and Health, 12 [2], 146-157. http://dx.doi. org/10.1108/09566160110389898.

16. Jeffrey, C. (2011) Construction and Demolition Waste Recycling a literature review. Dalhousie University`s Office of Sustainability. http://www.dal.ca/content/dam/dalhousie/pdf/sustainability/Final $\% 20 \mathrm{C} \% 26 \mathrm{D} \% 20$ literature $\% 20$ review.pdf. 